\title{
導波体を利用した遠距離超音波伝送システムの研究*
}

\author{
村山 理一"1, 小林 真之*2 ${ }^{* 2}$, 小林 牧子 ${ }^{* 3}$, 任 正魁 ${ }^{* 3}$
}

\section{Study of Ultrasonic Transmission System Using a Long Waveguide}

\author{
Riichi MURAYAMA* ${ }^{* 1}$, Masayuki KOBAYASHI, Makiko KOBAYASI and Cheng-Kuei JEN \\ ${ }^{* 1}$ Fukuoka Institute of Technology, Wajiro-higashi3-30-1, Higashi-Ku, Fukuoka, 811-0295 Japan
}

\begin{abstract}
The nondestructive inspection of a high temperature structure is required to guarantee its safety. However, there are not any useful sensors for high temperature structures. Some of them cannot work at temperatures over $50^{\circ} \mathrm{C}$. Another concern is that they are too expensive to use. The sensing system, which can transmit and receive an ultrasonic wave that travels a long distance using a long waveguide, has been studied. We could confirm that an optimal guided ultrasonic wave can travel more than $50 \mathrm{~cm}$ using a thin $2 \mathrm{~mm}$ diameter bar as the waveguide. However, we had a difficult problem of receiving a reflected ultrasonic wave from the bottom surface of a test specimen. We tried to improve the trial inspection system using an ultrasonic horn. Finally, an experiment in which the temperature of a test block was heated to about $270^{\circ} \mathrm{C}$ has been done and the reflected ultrasonic wave from the bottom surface was successfully detected.
\end{abstract}

Key Words : Nondestructive Inspection, High Temperature Structure, Ultrasonicwave, Waveguide, Remote Sensing

\section{1. 緒言}

高温構造物や原子炉内配管等の高温で放射線被爆のため人間が近づけない構造物の非破壊検査システムの開発 が多くの研究者によって行われている. しかし，一般に超音波センサは $50^{\circ} \mathrm{C}$ 以上では長期的使用が難しく，また 放射線ダメージも受けや寸い. 高温構造物にも適用可能な非接触センサとして, 電磁力を利用した超音波センサ （電磁超音波センサ）があるが，大規模な冷却設備が必要など種々の課題があり実質的な実用化例は殆どない. レーザ超音波を利用した検查システムは，外乱因子に弱く設備費用が高価（1 億円以上）であるために使用でき る構造物が限られている. そこで数百 ${ }^{\circ} \mathrm{C}$ 高温構造物に対して構造物の温度の影響を受けない充分な距離を離し た場所に超音波センサを設置し，超音波伝送媒体（導波体）を通して配管に超音波を送受信して安定かつ長期に わたって検査可能な比較的安価な検査システムを検討した.

\section{2. 高温構造物測定方法}

一般の超音波探触子は常温駆動であるため高温構造物に直接，接触させることはできない，そこで超音波探触 子と高温構造物の間を導波体で超音波を送受信寸ることを考えた。しかし充分に長い導波体でないと，導波体か らの温度伝達或いは, 高温の雰囲気温度により超音波探触子は損傷を受け易い. 逆に超音波探触子を運転室や機 械室のような常温環境下で駆動できるほど充分な距離を取ることができれば，超音波探触子が温度に弱いという 久点を解決できるので, 長期的に安定して高温構造物の検查が可能であると考えた ${ }^{(1)}{ }^{(2)}$. このような長い導波体 を伝搬する超音波モードとして, 距離伝搬減衰が比較的小さい低周波領域の縦振動モード（鋼の場合の音速は 約 $5,600 \mathrm{~m} / \mathrm{s}$ ）のガイド波を用いることとした. 導波体として想定される棒材や円管に対するガイド波の送受信に

\footnotetext{
* 原稿受付 2011 年 6 月 20 日

${ }^{* 1}$ 正員, 福岡工業大学工学部知能機械工学科（广811-0295 福岡県福岡市東区和白東 3-30-1）

${ }^{* 2}$ 学生員, 福岡工業大学工学部知能機械工学科

*3 カナダ国立研究機構材料研究所

E-mail: murayama@fit.ac.jp
} 
関する先行研究は数多くあり ${ }^{(3)(4)(5)}$, 湾曲部の影響についても多くの知見が得られているが(6) (7) (8) (9) (10), 音響ホー ンを用いた導波体と試験体との間の超音波送受信効率の向上に関する検討は多くはなされておらず，この点につ いて改善を試みた。また棒材や円管に対するガイド波の種々の発生方法についても既に検討されており (11) (12) (13) (14), 今回は電磁超音波法を中心に検討したが圧電素子を使う場合についても比較検討した.

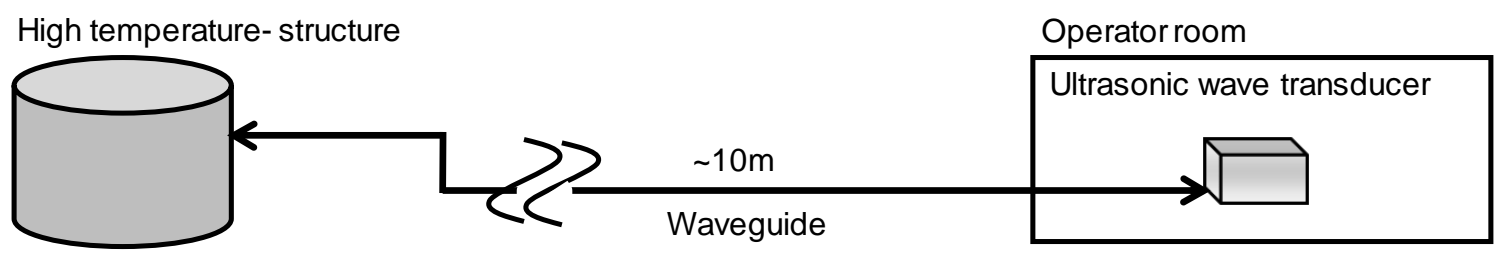

Fig.1 Basic concept of remote sensing by ultrasonic wave

\section{3. ガイド波駆動原理}

本研究では，ガイド波の駆動方法として，丸棒側面を利用した電磁超音波センサを適用した。図 2 は，電磁超 音波センサ利用タイプで, 細径棒端部側面にセンサコイルとそれを覆うようにして同心円状直流電磁石を配置し, 最も磁場変化に対して磁場変動が大きくなるような静磁場を丸棒表面に与え, 同時にセンサコイルによる動磁場 を同一箇所に与えることで充分な強度の磁歪振動が発生し，ガイド波に変換できる (15) (16) (17) (18) (19). 受信信号 は反射して戻ってきた超音波による高速振動と静磁場との相互作用によって発生するセンサコイル上に発生する 誘導電流を増幅することによって検出することができる.

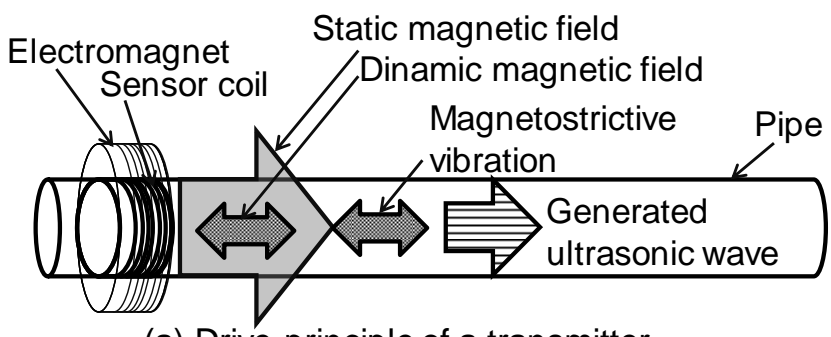

(a) Drive principle of a transmitter

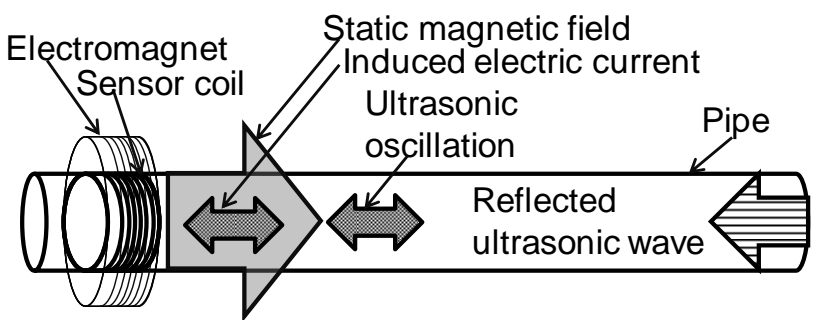

(b) Drive principle of a receiver

Fig.2 Drive principle of an electromagnetic acoustic sensor

\section{4.＼cjkstart導波体を用いた場合の構造物温度の影響}

実験を行うにあたって，第 1 ステップとしてどの程度の長さの導波体が適当か検討した．すなわち，高温実験 を行い，反対面温度が雰囲気温度とほぼ同じ温度が期待できる長さで，実験室的に扱いやすい長さを確認するこ とにした. 式 (1) は雾囲気温度が常温であることを仮定し, 丸棒反対端での熱の出し入れを仮定した場合の丸棒 各部の温度を示寸結果である ${ }^{(20)}$. 図 3 は雰囲気温度 $T$ を $20^{\circ} \mathrm{C}$ とた解析結果で反対端面（高温材料側）の温度 が $500^{\circ} \mathrm{C}$ 程度までは, 棒の長さ $50 \mathrm{~cm}$ 以上で棒の直径にはあまり関係なく端面温度は常温になることが確認できた。 したがって本研究では，基本的な特性実験は，長さ $50 \mathrm{~cm}$ の試験棒を利用して実施した。

$$
\begin{aligned}
& \Theta=\frac{\cosh [m(H-x)]+\alpha \bullet \sinh [m(H-x)] /(m \bullet \lambda)}{\cosh (m \bullet H)+\alpha \bullet \sinh (m \bullet H) /(m \bullet H)} \\
& m=\sqrt{(\alpha \bullet S) /(\lambda \bullet A)} \quad \Theta=\left(T-T_{b}\right) /\left(T_{0}-T_{b}\right)
\end{aligned}
$$

\footnotetext{
$\Theta$ : 導波体高温端温度と雰囲気温度の差に対する導波体任意位置 $(x)$ での温度指標

$H$ : 棒の長さ, $x$ : 棒の高温端からの距離, $\lambda$ : 熱伝導率, $\alpha$ : 熱伝達率, $A:$ 棒の断面積

$S:$ 棒の周長, $T_{0}$ : 高温端の温度, $T_{\mathrm{b}}$ : 雾囲気温度, $T: x$ の位置での温度
} 


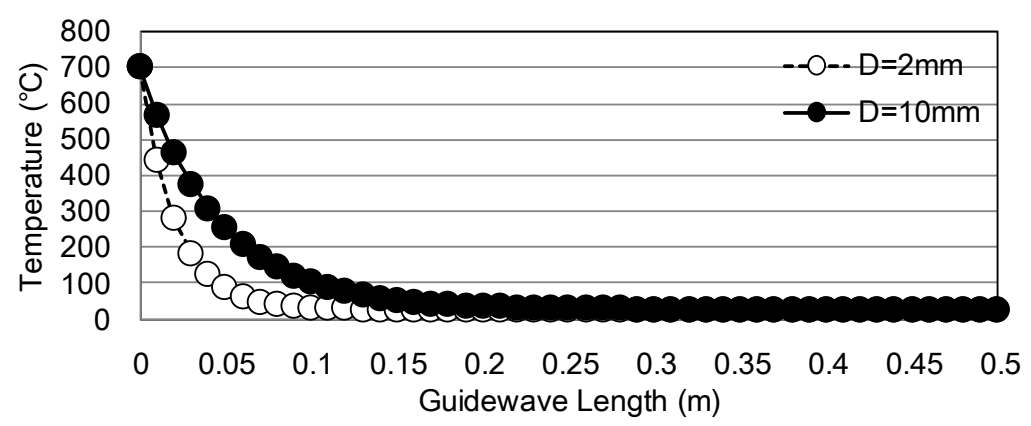

Fig.3 Computation results of temperature distribution in a bar

\section{$5 \cdot 1$ 実験システム}

\section{5. 実験結果}

図 4 に実験システムを示寸，高出力高周波信号（最大 $200 \mathrm{Vp}-\mathrm{p}$ ，最大 $2 \mathrm{MHz}$ ）は，波形発生器とパワーアンプ を組み合わせて発生させた，図 2 （b）の電磁超音波センサを用いる場合は，直流電磁石を駆動するための直流電 源（最大出力電圧 $40 \mathrm{~V}$, 最大電流 $3 \mathrm{~A}$ ) も同時に使用した. 受信信号は, 前置増幅器 (増幅度 $40 \mathrm{~dB}$, 増幅帯域 $5 \mathrm{MHz}$ ) を通過させた後, 主増幅器（最大増幅度 $60 \mathrm{~dB}$, 増幅帯域 $50 \mathrm{kHz} \sim 2 \mathrm{MHz}$ ）で一定の信号強度にした後, オシロス コープ及びCPUに取り込まれ，信号振幅，周波数分布，超音波音速等が評価され，構造物の非破壊検査が可能か どうかを評価した.なお, PZT 圧電素子を超音波送受信センサとして使用する場合は, RITEC 社製の Diode Expander を使用して送信電気信号の増幅器側への漏れ込みを抑制した，また，遠距離伝送体を接触させた試験片を加熱す ることで，高温構造物に適用する場合についても検討した.

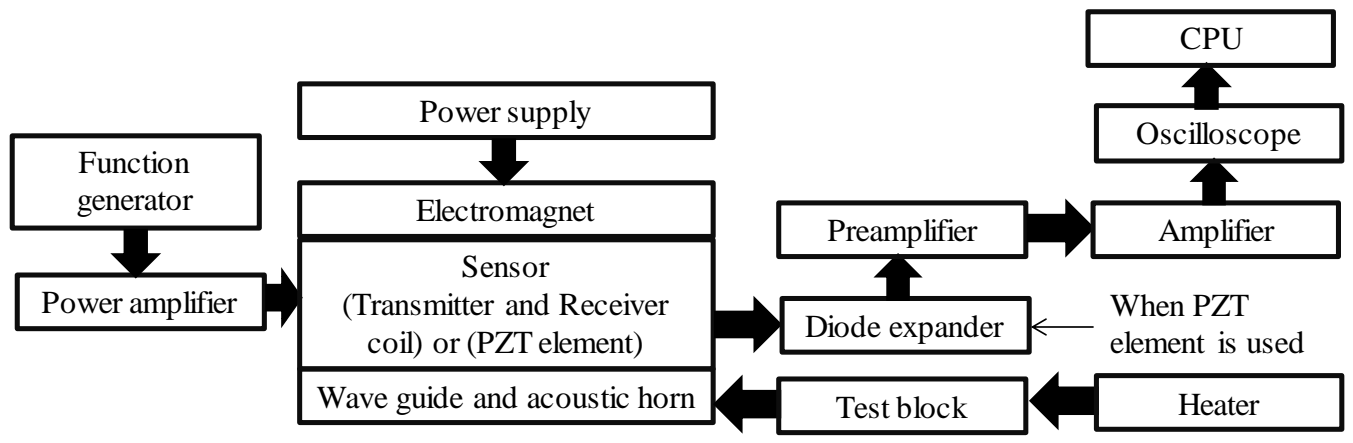

\section{$5 \cdot 2$ 試験片}

Fig.4 Diagram of experimental system

試験片として，高温構造物から常温領域までの配置が比較的簡単と考えられる丸棒を用意した，材質は一般構 造用炭素鋼で，長さは $500 \mathrm{~mm} ，$ 直径は作業性及びガイド波発生の容易さも考慮し， $2 \mathrm{~mm} ， 4 \mathrm{~mm}, 6 \mathrm{~mm}, 8 \mathrm{~mm}$ の 4 種類 を用意した。

\section{$5 \cdot 3$ 電磁超音波センサの最適化}

最初に接触媒質が不要で，比較的再現性の高い実験結果が得られる電磁超音波センサの駆動方法の最適化を実 施した。最適化のために確認した受信信号は，丸棒端面近傍に設置したセンサ部から発信したガイド波が，丸棒 他端で反射して戻ってきた信号を 126 回平均し, 信号波形のピーク信号電圧と反射信号が存在しない部分のノイ ズ信号強度の比 $(\mathrm{dB})$ を評価した。

電磁超音波センサを構成する電磁石については，被検材に与える動磁場に対して磁歪振動が最も大きくなるバ イアス磁場に設定する必要があり, 試験片として用意した丸棒の径より $5 \mathrm{~mm}$ 大きな直径で長さ $50 \mathrm{~mm}$ の中空芯 に, 直径 $0.89 \mathrm{~mm}$ の銅線を 1000 回巻いた電磁石の駆動電流を変更していき, 受信信号強度が最大になる電流值を 丸棒径 2，4，6，8mm に対して，0.9（A）１.0（A）１.2（A），1.5（A）に設定した.

電磁超音波センサを構成するセンサコイル巻数の最適化例として $2 \mathrm{~mm}$ 径の丸棒を利用した結果を図 4 に示寸. 受信センサ巻数を固定して，送信センサ巻数を 3-20 の間で選定を行った. 図 5 (a) に送信センサの選定結果を 
示すが, 10 巻きが最適值となった. また，送信センサを最適巻数にし，受信センサ巻数 5-125 の間で検討した. 図 5 （b）に受信センサ検討結果を示すが 75 巻きが最適值となった．なお，この巻き数 10,75 のコイルインピー ダンスは, 各々約 $45 \Omega, 210 \Omega$ となっており, パワーアンプや増幅器とのインピーダンス整合の結果が反映され ていると考えられる. 同様の方法で丸棒径毎にセンサコイル巻き数の最適化を行った後, 丸棒径 $4,6,8 \mathrm{~mm} に$ 対して, 送信センサコイルの巻き数を $5,4,3$ 巻き, 受信センサコイルの巻き数を $50,40,30$ 巻きと決定し評価 実験を実施した．また $2 \mathrm{~mm}$ 径の丸棒を使ってセンサコイルに流寸高周波電流の周波数を 0.1-3（MHz）で変化さ せ， S/N の比較を行った結果を図 5 (c) に示寸.この結果より，0.2（MHz）を駆動周波数として決定し，他の丸 棒径についても同じ駆動周波数を用いた。

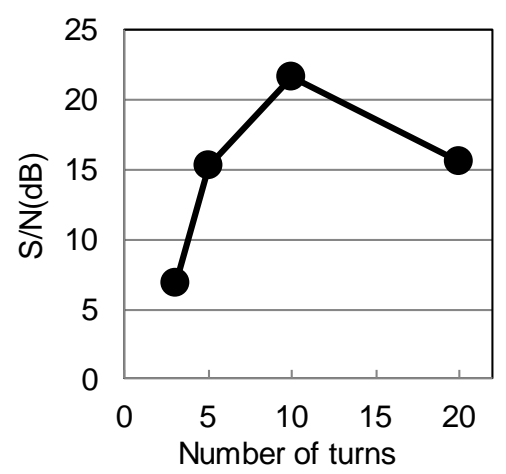

(a) Best number of turns of a transmitter

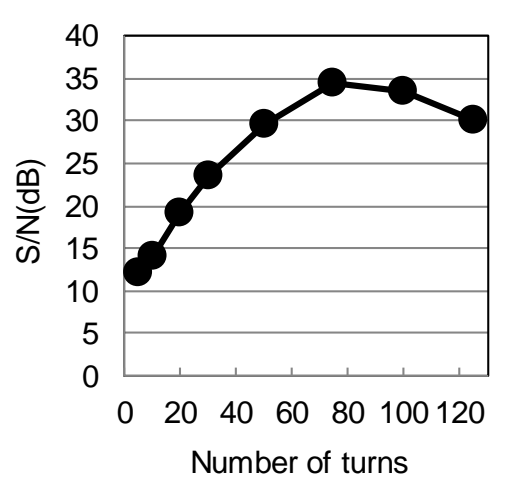

(b) Best number of turns of a receiver

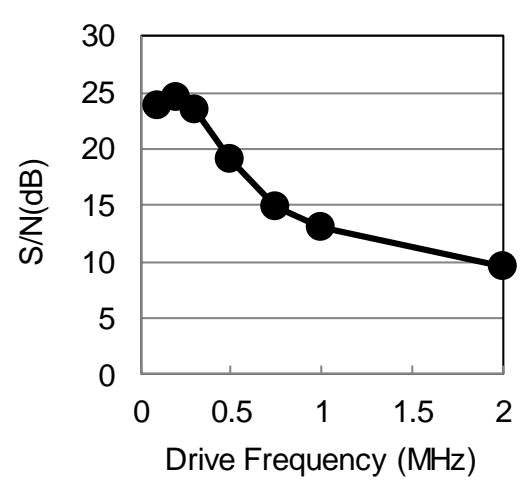

(c) Best drive frequency

Fig.5 Optimum drive condition of the trial electromagnetic acoustic transducer

\section{$5 \cdot 4$ 導波体選定}

導波体として使用した丸棒の最適径を決定するために， $2 \mathrm{~mm}$ 径〜 $8 \mathrm{~mm}$ 径の丸棒の場合について，丸棒端面か らの超音波反射信号を測定した。図 6 （a）は 8 mm 径の場合，図6（b）は $2 \mathrm{~mm}$ 径の場合の受信信号波形例であ り，直径が小さくなるほど強い受信信号波形が得られることがわかる. 丸棒の直径による受信信号波形の変化の 様子を示したのが図 7 で，図 7 (a) が丸棒径と受信信号の第一反射波の $\mathrm{S} / \mathrm{N}(\mathrm{dB})$ の関係を示しており，図 7 (b) は, 多重反射信号から求めた距離減衰係数 $(\mathrm{dB} / \mathrm{m})$ を示している. 丸棒径が小さくなる程, 端面反射信号の $\mathrm{S} / \mathrm{N}(\mathrm{dB})$ は高くなり，また距離減衰率も小さくなった。ノイズ信号レベルは同じまま距離減衰率と伝搬距離に比例して信 号強度が低下寸ると考え, 多重反射信号の $\mathrm{S} / \mathrm{N}(\mathrm{dB})$ が 2 になるまでの伝搬距離を図 7 (a)，（b）のデータから計算 寸ると, 直径 $8 \mathrm{~mm}$ は実質測定不可, 直径 $4 \mathrm{~mm}$ で約 $1.9 \mathrm{~m}$, 直径 $4 \mathrm{~mm}$ で約 $11.2 \mathrm{~m}$, 直径 $2 \mathrm{~mm}$ で約 $57.5 \mathrm{~m}$ を示して いる. すなわち丸棒 $2 \mathrm{~mm}$ を導波体として使用し, 電磁超音波法センサの最適化を行った場合, 構造物の温度の 影響を受けない充分な距離から, 超音波の送受信が可能であるという結果を得た. この結果は速度分散曲線を図 7 (c) で示寸ように，ガイド波位相速度が低周波数領域では速度分散性が小さくなるため信号強度が大きくなる ことが影響していると考えられる.ただし，直径が $2 \mathrm{~mm}$ 未満の場合に，さらに長距離伝搬できる可能性は残さ れているが, 実際の材料への入射効率等を考慮し, 本研究では直径 $2 \mathrm{~mm}$ を適切な導波体の大きさとした.

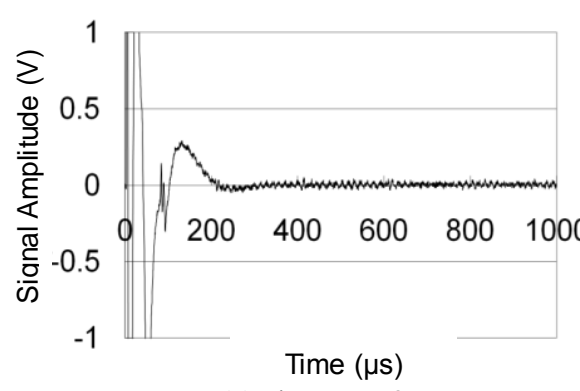

(a)Diameter $=8 \mathrm{~mm}$

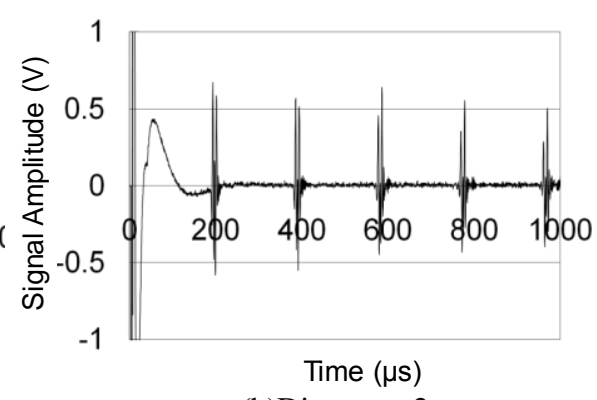

(b)Diameter $=2 \mathrm{~mm}$

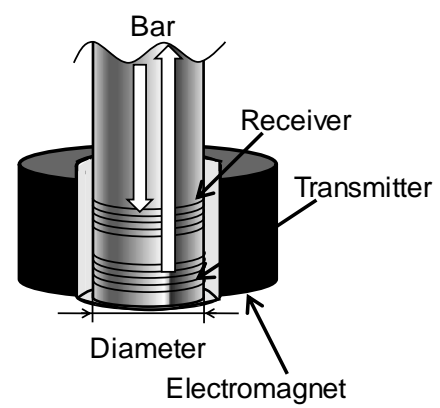

Electromagnet

Fig.6 Received ultrasonic wave signal with only a waveguide 


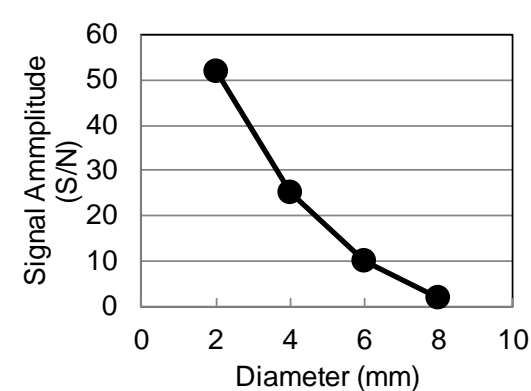

(a) Signal amplitude

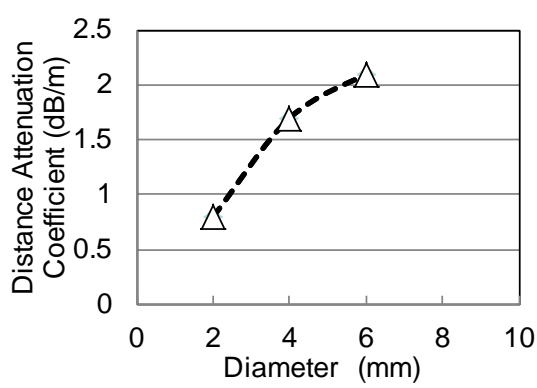

(b) Distance attenuation coefficient

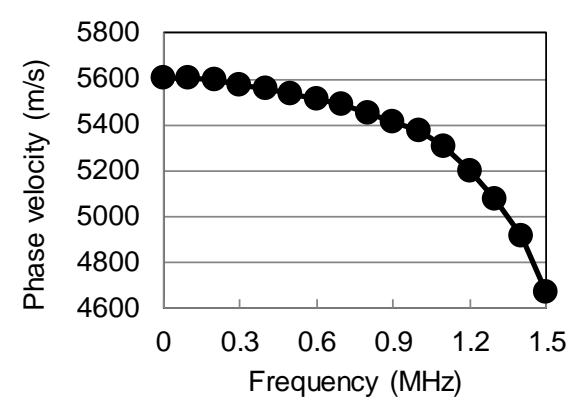

(c) Phase velocity and Frequency

Fig.7 Relation between the received signal feature due to the diameter of the bar and phase velocity on drive frequency

\section{$5 \cdot 5$ 音響ホーン選定}

図 8 （a）に選定した導波体を用いて $25 \mathrm{~mm}$ 試験片に超音波を伝播させた受信信号波形例を示寸．導波体内のガ イド波の多重信号は，導波体単独の場合と同様に良好に検出できたが，試験体からの底面反射信号を検出するこ とはできなかった．この原因は，導波体の直径が $2 \mathrm{~mm}$ と小さいため，試験体に入射した超音波ビームの指向角 が大きく，発散してしまうためと考えられた．そこで確認のため，音速が鋼に比べ約 $1 / 4$ となる水を用いること で指向角を小さくして実験を行った. 図 8 （b）は水深 $100 \mathrm{~mm}$ の場合，図 8 (c) は水深 $25 \mathrm{~mm}$ の場合である. 水 深 $25 \mathrm{~mm}$ で, 水槽底面からの反射信号を確認でき, 指向角を小さく寸ることが有効であることが有効であること が確認できた.

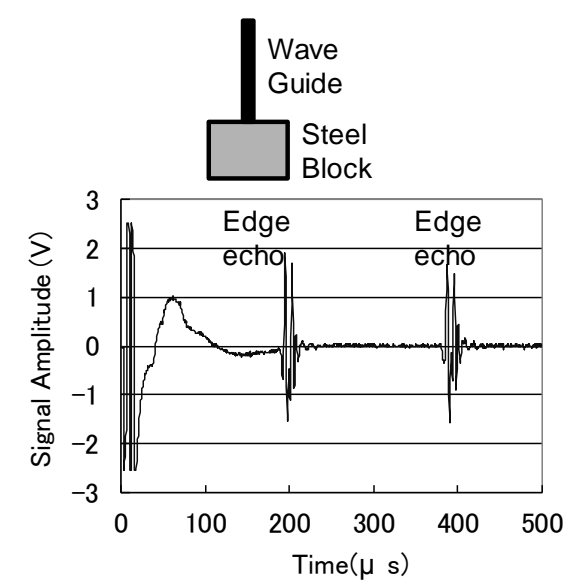

(a) Steel (25mm)

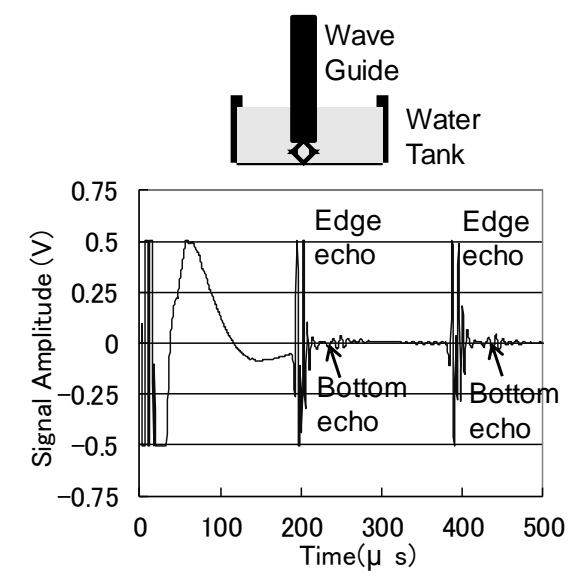

(b) Water $(25 \mathrm{~mm})$

Fig.8 Reflected ultrasonic wave signal from the specimen using the only waveguide

超音波長距離伝搬には細い径の導波体が有効であることは確認できたが，試験片に超音波を送受信させる事が 困難であることが明らかになったため導波体と試験体の間に音響ホーンを検討した．検討した音響ホーンは当初 は円筒状であったが超音波が伝播する際には音響ホーン内を拡がりながら伝播するため円錐の底面に超音波が到 達する時間は底面の中心と底面の外側で異なり，結果として音響ホーンから試験体に超音波が入射する段階では 円錐底面の位置によって入射時間が変化し指向角を小さくする効果が得られず，さらに導波体と円筒状音響ホー ン間で面積比に対応した伝達ロスが有ると考えた．そこで円錐形状にして導波体と音響ホーンの間の伝達ロスを 最小限にすることで導波体だけの時と比較して広い範囲の超音波を受信できるようになり信号強度が高くなる可 能性があると考えた，検討した音響ホーン形状の概要図を図 9 に示す．音響ホーンの無い図 9 (a) に対して，円 筒型ホーンを示したのが図 9 (b) で直径は 4mm, 10mm, 20mm, 30mmにし, 長さは発生させているガイド波の波長 と同じ長さの $25 \mathrm{~mm}$ にした，次に円錐型ホーンである図 9 （c）を，試験対接触面の直径を $4 \mathrm{~mm}, 10 \mathrm{~mm}, 20 \mathrm{~mm}, 30 \mathrm{~mm}$ にし，長さは発生させているガイド波の波長と同じ $25 \mathrm{~mm}$ と半波長に相当する $12.5 \mathrm{~mm}$ にした。製作した音響ホー ンの仕様を表 1 に示した. また縦軸を試験片からの第一反射信号と第一反射信号周辺のノイズ信号レベルとの比 $(\mathrm{S} / \mathrm{N}(\mathrm{dB}))$ とした場合の実験結果を図 10(a)に示す. 円筒型に比べて円錐型の方がより良い結果が得られ, 試験体表 
面に接触する面は直径 $20 \mathrm{~mm}$ の場合が最も良好な結果であった．またホーンの長さは半波長の場合が最も良好で あった. 図 10 (b) に円筒型で $20 \mathrm{~mm}$ 径, 1 波長長さの音響ホーンを用いた場合, 図 10 (c) に最も良好な受信信号 が得られた円錐型で $20 \mathrm{~mm}$ 底面径, 半波長の場合の受信信号波形例を示寸が円錐型で試験体底面からの反射信号が 検出できている.
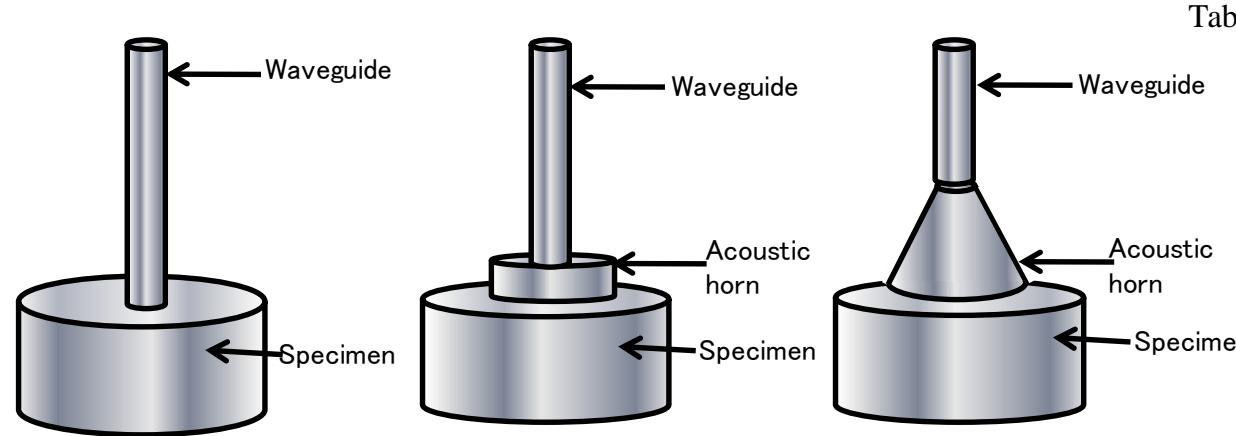

Table1 Specification of acoustic horn

(a) waveguide

(b) Waveguide + Cylindrical horn

(c) Waveguide + Corn horn

\begin{tabular}{|c|c|c|c|}
\hline Number & Shape & $\begin{array}{c}\text { Diameter } \\
(\mathrm{mm})\end{array}$ & $\begin{array}{c}\text { Height } \\
(\mathrm{mm})\end{array}$ \\
\hline$(1)$ & cylinder & 4 & 30 \\
\hline 2 & cylinder & 10 & 30 \\
\hline 3 & cylinder & 20 & 30 \\
\hline 4 & cylinder & 30 & 30 \\
\hline 5 & corn & 4 & 30 \\
\hline 6 & corn & 10 & 30 \\
\hline 7 & corn & 20 & 30 \\
\hline 8 & corn & 30 & 30 \\
\hline$(9)$ & corn & 4 & 15 \\
\hline 10 & corn & 10 & 15 \\
\hline 11 & corn & 20 & 15 \\
\hline$(12)$ & corn & 30 & 15 \\
\hline
\end{tabular}

Fig.9 Outline of trial acoustic horns

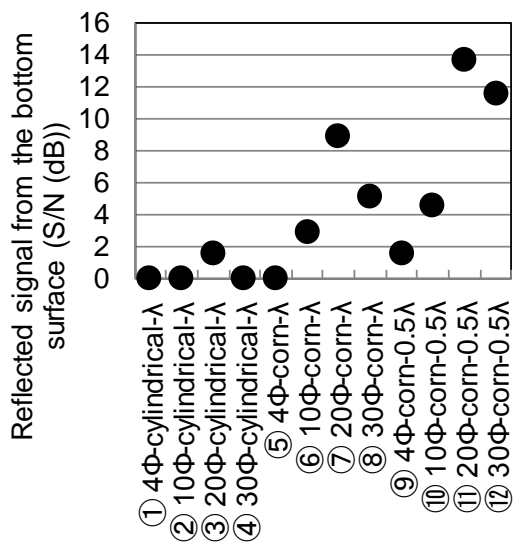

(a) Signal amplitude for acoustic horns

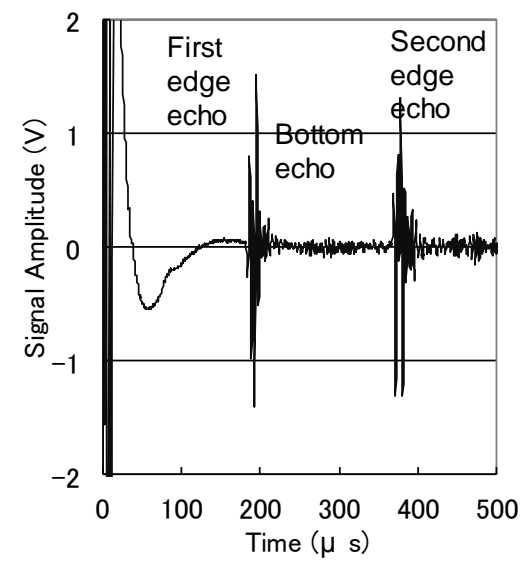

(b) Signal waveform using $20 \mathrm{~mm}$ diameter cylinder $\lambda$ horn

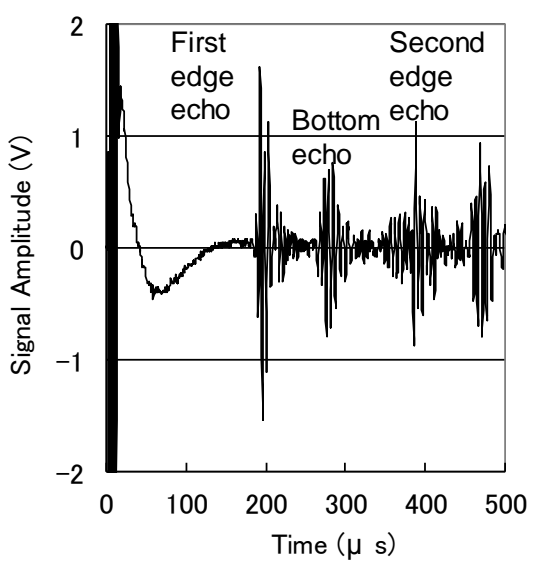

(c) Signal waveform using $20 \mathrm{~mm}$ diameter corn $0.5 \lambda$ horn

Fig.10 Experimental results using many acoustic horns

\section{$5 \cdot 6$ エルボ部の影響評価}

導波体を使って，高温構造物から，常温スペースまで超音波の送受信を実施する場合，直線部だけで敷設でき る場合は少ないと考えられる．エルボの影響については外側と内側の伝播距離差によって，波面が歪むため，工 ネルギー損失やノイズ，疑似信号の発生を引き起こすことが言われている(9)(10)．そこで導波体の中央部を曲げて いき，その影響を確認した．図11はその実験結果で，エルボ部が増加するとエルボ部からの反射信号が顕著にな り，導波体の端から端まで超音波を送受信することが困難であることがわかった．今後，曲率半径等の曲部の仕 様を再検討し，より使用範囲が広い条件の探索を進める.

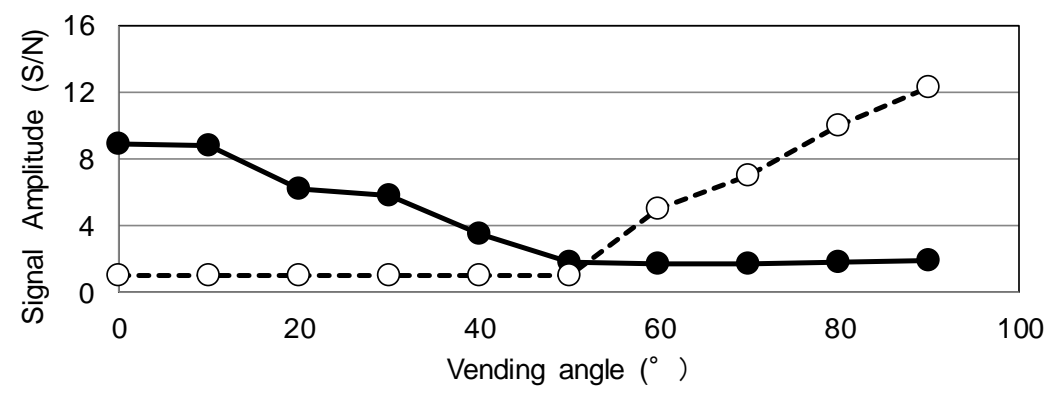

Fig.11 Influence of a received ultrasonic wave signal by a vent part of the waveguide 


\section{$5 \cdot 7$ 材料温度の影響}

試験材温度を加熱した場合の導波体反対端の温度及び受信信号波形の変化を確認した．試験体はヒーターを用 いて常温から 270 迄加熱した。 図 12 (a) は，導波体の試験体接触面側温度と反対端温度の関係を示している. 反対端温度は 20 度以内の温度上昇になっており, 図 11(b) と比較して図 12（b）に示寸ように受信信号波形に影 響がないことも確認できた。

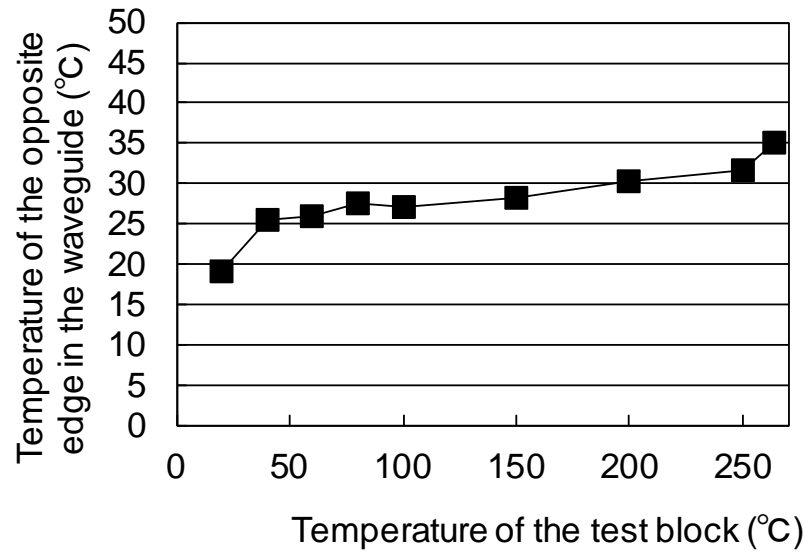

(a) Relation between the temperature of the test block and the opposite edge of the waveguide

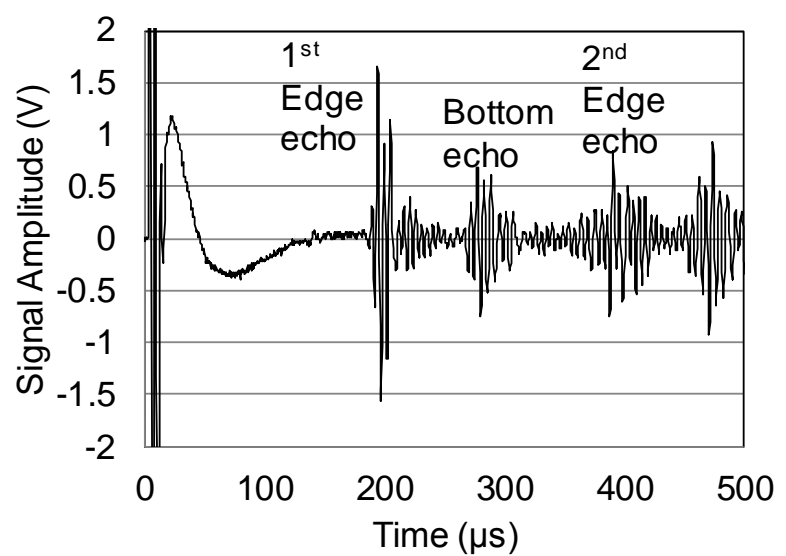

(b) Receive signal waveform at $268{ }^{\circ} \mathrm{C}$

Fig.12 Influence of a received ultrasonic wave signal by the temperature of the test specimen

\section{$5 \cdot 8$ 導波体の長さの影響}

導波体長を $0.5 \mathrm{~m}, 1 \mathrm{~m}, 2 \mathrm{~m}, 4 \mathrm{~m}$ に延長して $100 \mathrm{~m}$ 厚の鋼ブロックの底面反射信号を確認した. 導波体 $4 \mathrm{~m}$ は $2 \mathrm{~mm}$ 径 $\times 2 \mathrm{~m}$ 長の細径棒 2 本の端面を TIG 溶接して準備した. 図 13 (a) は導波体 $4 \mathrm{~m}$ に底面半径 $20 \mathrm{~mm}$ の円錐ホーン をつけた場合の受信信号波形で，試験体の底面反射波を確認できた。図 13 （b）は，導波体長さと底面反射信号 の関係を示しており，導波体長 $0.5,1 ， 2 \mathrm{~m}$ では，導波体長 $1 \mathrm{~m}$ の場合が少し高い值を示しているが導波体の支持 条件を完全に同一化できなかったためと考えられ，図 7(b)で示した距離減衰率 $0.75(\mathrm{~dB} / \mathrm{m})$ に対応した結果と考え られる．ただし導波体 $4 \mathrm{~m}$ では，距離減衰率を考慮しても信号の減衰度は大きく溶接部の影響ではないかと考え られる.今後, 溶接部の無い長い細径棒を利用することで, より長距離での超音波の送受信が確認できると考えら れる。

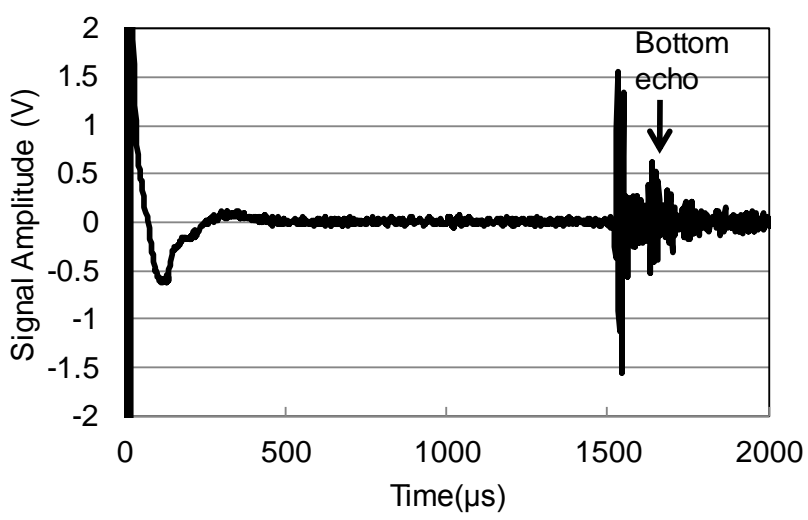

(a) Received ultrasonic signal (Waveguide $=4 \mathrm{~m}$ )

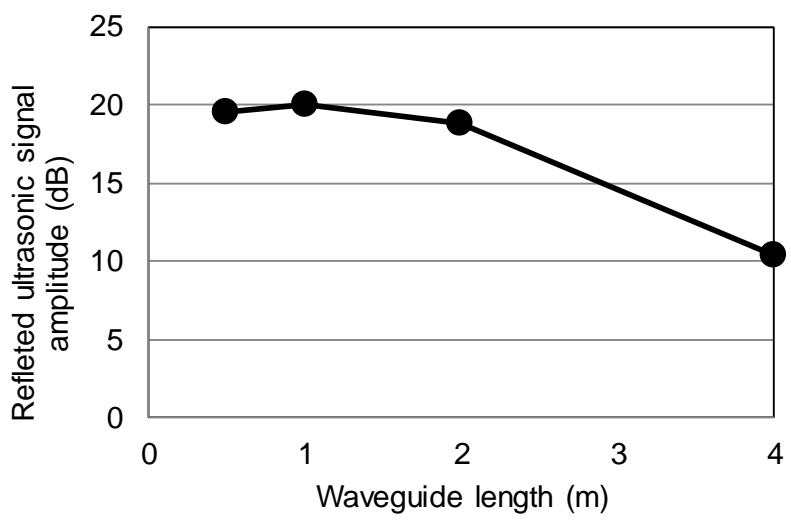

(b) Thickness signal amplitude and waveguide length

Fig.13 Influence of a received ultrasonic wave signal length of the waveguide

\section{$5 \cdot 9$ 導波体底面部を利用したガイド波駆動法の検討}

本報告では電磁超音波センサを用いて導波体端部側面でのガイド波の送受信の送受信を実施した。しかしガイ 
ド波の送受信方法としては導波体底面部で行うこともできる．そこで $4 \mathrm{~mm}$ 直径 $\times 15 \mathrm{~mm}$ 厚で $200 \mathrm{kHz}$ 駆動の圧電振 動子を $2 \mathrm{~mm}$ 直径 $\times 500 \mathrm{~mm}$ 長の導波体底面に油を介して貼り付け実験を行った。図 14 (a) は受信信号波形例を示 す.反対端からの反射信号強度をオシロスコープ上で同一振幅になるように調整した増幅器の増幅度は 20 (dB) となり, 電磁超音波センサの場合の $33 \mathrm{~dB}$ よりも小さくなったが, $\mathrm{S} / \mathrm{N}(\mathrm{dB})$ として明らかに劣る結果となった. この理由は, 超音波の送受信能力として圧電振動子は優れているが, 発生する超音波ビームの進行方向がランダム になっていると考えられ，ガイド波のみでなく導波体端面で反射しながら伝搬していく超音波も発生しているこ とが一因ではないかと考えられる.また同一条件で両センサを順繰りに 20 回繰り返し測定した場合の受信信号強 度のばらつきを図 14 （b）に示す，再現性は電磁超音波センサに比べて劣る結果となった．この理由は圧電振動 子の接触方法に起因寸ると考えられ接着剂で固定する等の実験方法の改善が必要である. 細径棒に縦振動モード のガイド波を送受信する方法としては Ni 箔を利用する方法も広く用いられており, 実用化時の利便性も考慮して 様々なガイド波送受信方法について検討が必要である.

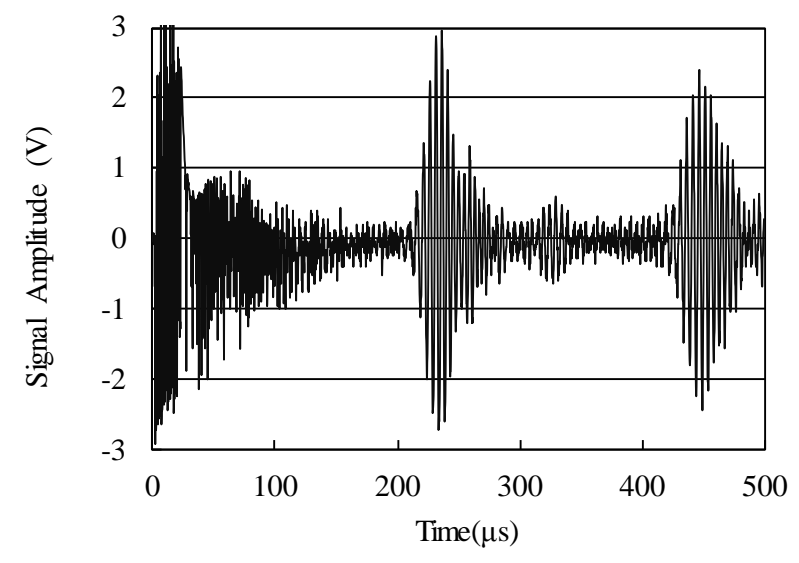

(a) Received signal using PZT element

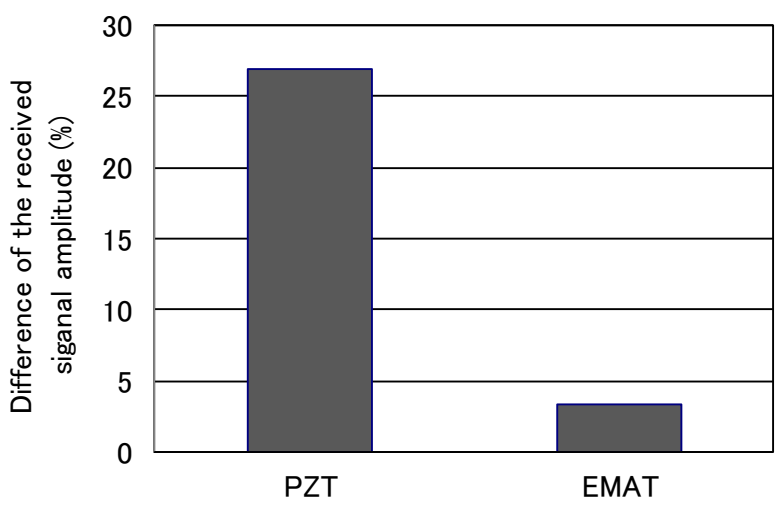

(b) Difference of received signal amplitude using a PZT element and an electromagnetic acoustic transducer

Fig.14 Evaluation results using a PZT oscillator

\section{6. 結言}

超音波を高温構造物の影響を受けない長距離から伝送できる可能性がある導波体として $2 \mathrm{~mm}$ 直径の丸棒を決 定し，送受信する超音波センサの仕様を最適化することで $4 \mathrm{~m}$ 長の導波体を使用した場合でも導波体反対面の反 射信号を検出することができた. しかし, 導波体だけでは,超音波ビームが試験体に入射するときに発散するため, 試験体の底面反射信号を明確に受信することはできなかった。そこで導波体と被検材の間に音響ホーンの適用を 検討し，その長さが使用するガイド波の半波長で，底面が $20 \mathrm{~mm}$ 直径の円錐型が最も明瞭に試験体の底面反射信 号を検出することができた．すなわち超音波長距離伝送には細い導波体と円錐型音響ホーンの組み合わせが有効 であることが確認できた。しかし試験体の寸法や必要な伝送距離などによって導波体の最適径や音響ホーンの仕 様は異なると考えられる. また $0.5 \mathrm{~m}$ 長の導波体と円筒型音響ホーンを使って試験体を約 270 度まで上昇させて も超音波センサ設置部は常温に維持できることを確認した．また導波体が湾曲した場合，湾曲角度が大きくなる につれて湾曲部からの反射信号も検出されることもわかった。 したがって, 高温構造物から常温スペースまで導 波体を設置する場合，大きな湾曲部を発生しない敷設方法も検討する必要がある.

\section{参考文献}

(1) Tittmann B.R., and Aslan M., "Ultrasonic Sensors for High Temperature Applications”, Japanese Journal of Applied Physics, Vol.38 (1999), pp.3011-3013.

(2) Tittmann B.R., "A Novel Technique with a Magnetostrictive Transducer for in Situ Length Monitoring of a Distant Specimen”, Ultrasonic Nondestructive Evaluation for Material Science and Industries, Vol.456 (2003), pp.73-78.

(3) 西野 秀郎，“非破壊計測のためのガイド波の基礎と展望”，非破壊検査，Vol.52, No.12 (2003), pp.654-661. 
（4）山崎 友裕，“ガイド波用電磁超音波センサによるワイヤ, パイプ, 薄板の非破壊評価”，非破壊検査，Vol.54, No. 11 (2005), pp.606-611.

（5）小倉 圭二，近藤 浩徳，吉田 憲一，西野 秀郎，“反射体を用いたガイド波の高効率励起検出法による欠陥検出 性能の検証”，非破壞検査，Vol.59, No.9 (2010), pp.466-467.

(6) 田中 俊郎, 増田 修一, 吉田 憲一, 西野 秀郎, “エルボ管を伝搬する $\mathrm{T}(0,1)$ モードガイド波のモード変換”, 日本機械学会年次大会講演論文集(2009), pp.453-454.

(7) 西野 秀郎, 吉田 憲一, 長 秀雄, 竹本 幹男, “パイプエルボ部におけるガイド波のモード変換”, 日本機械学会 年次大会講演論文集 (2005), pp.657-658.

(8) 古川敬，古村一朗，“エルボ管及び溶接部におけるガイド波伝搬シミュレーション”, 超音波 techno, Vol.22, No. 6 (2010), pp.20-24.

（9）卯西 裕之，石川 昌己，大谷 靖弘，“ガイド波を用いた配管腐食検查技術”，NKK技法，No.277 (2002), pp.38-42.

（10）増田秀一，田中俊郎，吉田憲一，西田秀朗，“ガイド波のエルボ管における伝搬挙動と欠陷検出感度”，日本機 械学会年次大会講演論文集 (2009), pp.455-456.

(11) 近藤 浩徳, 加藤 泰久, 吉田 憲一, 西野 秀郎, “MsS センサーによるガイド波の効率的送受信に関する研究”, 日本機械学会講演論文集 (2007), pp.65-66.

(12) 田中 義和，池田 隆，問山 清和，桑子 創太郎，藤本 由紀夫, “圧電フィルムを用いたガイド波計測の基礎的 研究”，日本機械学会論文集 A 編， Vol.72, No.718 (2006), pp.951-956.

(13) 山崎 友裕, 玉井 進悟, 平尾 雅彦, “軟鋼ワイヤの縦波用多段電磁超音波センサの開発”, 日本機械学会論文集 $\mathrm{A}$ 編, Vol.65, No.630 (1999), pp.400-405.

(14) 山崎 友裕, 玉井 進悟, 河部 大輔, 白山 泰久, 平尾 雅彦, “電磁超音波センサによる軟鋼ワイヤのロングレンジ 探傷”，日本機械学会論文集 A 編，Vol.65, No.640 (1999), pp.2456-2462.

(15) 山崎 友裕，玉井 進悟，平尾 雅彦，“軟鋼ワイヤの縦波用電磁超音波センサの送受信特性”，日本機械学会論文集 A 編, Vol.65, No.633 (1999), pp.1038-1043.

(16) Thompson R.B., "A Model for the Electromagnetic Generation and Detection of Rayleigh and Lamb Wave”, IEEE Transaction on SONICS AND ULTRASONICS, Vol.20 (1973), pp.340-346.

(17) Hirao M., and Ogi H., EMATS for Science and Industry (2003), p.372, Kluwer Academic Publishers.

(18) Ogi H., Goda E., and Hirao M., "Increase of Efficiency of Magnetostriction SH-Wave EMAT by Angled Bias Field”, Japanese Journal of Applied Physics, Vol.42 (2003), pp.3020-3024.

(19) Hirao M., Ogi H., and Yasui H., "Contactless measurement of bolt axial stress using a shear-wave electromagnetic acoustic transducer”, NDT \& E International, Vol.34 (2001), pp.179-183

(20) 伊藤 猛宏, 高田 保之, 計算して理解する熱工学, (1996), p.174, 丸善. 